\title{
RELASI KETERAMPILAN MEMBACA KRITIS DAN BERPIKIR LOGIS DENGAN KUALITAS PENULISAN SKRIPSI KUANTITATIF MAHASISWA PENDIDIKAN AGAMA ISLAM STIT PEMALANG
}

\author{
Mar'atul Lutfiyah \\ Universitas Wahid Hasyim Semarang \\ mlutfiyah@gmail.com
}

\begin{abstract}
This study aims to: (1) determine the relationship between critical reading skills and the quality of PAI students' quantitative thesis writing, (2) find out the relationship between logical thinking and PAI Student's quantitative thesis quality, (3) find out the relationship between critical reading skills and logical thinking together with the quality of quantitative thesis writing for PAI students. This research is a quantitative research with a design of product moment correlation analysis and multiple linear regression. The study was conducted at the Pemalang Tarbiyah College of Sciences (STIT). The population is 100 students. The sample was taken by proportionate stratified random sampling of 65 students. Data was collected through questionnaires. Data analysis includes descriptive analysis, testing analysis prerequisites, and hypothesis testing. The results showed that: (1) there was a positive and significant relationship between critical reading skills and the quantitative quality of PAI students' thesis, (2) there was a positive relationship and significance between logical thinking and PAI Student's quantitative thesis quality, (3) positive and significance between critical reading skills and logical thinking with the quality of quantitative thesis writing for PAI students. This means that the quality of quantitative thesis writing of $P A I(Y)$ students can increase by improving critical reading skills (X1) and the ability to think logically (X2).
\end{abstract}

Keywords: critical reading, logical thinking, and quantitative thesis

\begin{abstract}
Abstrak
Penelitian ini bertujuan untuk: (1) mengetahui hubungan antara keterampilan membaca kritis dengan kualitas penulisan skripsi kuantitatif Mahasiswa PAI, (2) mengetahui hubungan antara berpikir logis dengan kualitas skripsi kuantitatif Mahasiswa PAI, (3) mengetahui hubungan antara keterampilan membaca kritis dan berpikir logis secara bersama-samadengan kualitas penulisan skripsi kuantitatif Mahasiswa PAI. Penelitian ini merupakan penelitian kuantitatif dengan desain analisis korelasi product
\end{abstract}


moment dan regresi linear ganda. Penelitian dilaksanakan di Sekolah Tinggi Ilmu Tarbiyah (STIT) Pemalang. Populasi sebanyak 100 Mahasiswa. Sampel diambil secara proportionate stratified random sampling sebanyak 65 Mahasiswa. Data dikumpulkan melalui angket. Analisis data meliputi analisis deskriptif, pengujian prasyarat analisis, dan pengujian hipotesis. Hasil penelitian menunjukkan bahwa: (1) ada hubungan yang positif dan signifikan antara keterampilan membaca kritis dengan kualitas skripsi kuantitatif Mahasiswa PAI, (2) ada hubungan yang positif dan signifikansi antara berpikir logis dengan kualitas skripsi kuantitatif Mahasiswa PAI, (3) ada hubungan yang positif dan signifikansi antara keterampilan membaca kritis dan berpikir logisdengan kualitas penulisan skripsi kuantitatif Mahasiswa PAI. Hal ini berarti bahwa kualitas penulisan skripsi kuantitatif Mahasiswa PAI (Y) dapat meningkat dengan meningkatkan keterampilan membaca kritis $\left(\mathrm{X}_{1}\right)$ dan kemampuan berpikir logis $\left(\mathrm{X}_{2}\right)$.

Kata kunci: membaca kritis, berpikir logis, danskripsi kuantitatif

\section{A. Pendahuluan}

Skripsi merupakan salah satu bentuk karya tulis ilmiah yang dihasilkan oleh mahasiswa sebagai syarat mendapatkan gelar sarjana. Menurut Dalman, skripsi adalah karya tulis di tingkat sarjana muda (biasanya dijadikan sebagai syarat untuk ujian sarjana muda), yang umumnya didasarkan atas penyelidikan bahan-bahan bacaan atau observasi lapangan. ${ }^{1}$

Heri Jauhari menambahkan bahwa skripsi adalah karya ilmiah yang dibuat oleh mahasiswa Strata Satu (S1) sebagai salah satu syarat untuk mendapatkan gelar sarjana. Karya ilmiah tersebut berisi proses dan hasil penelitian, baik penelitian studi pustaka maupun penelitian lapangan. ${ }^{2}$ Agar diakui keilmiahannya, kebenarannya harus dipertanggungjawabkan di depan penguji. Tujuannya adalah untuk melihat apakah skripsi yang dibuat mahasiswa tersebut benar-benar hasil karya ilmiah yang

${ }^{1}$ Dalman, Menulis Karya Ilmiah, (Jakarta: Rajawali Pers, 2015), hlm. 199.

${ }^{2}$ Dalman, Menulis Karya Ilmiah, hlm. 200. 
ditulisnya sendiri dan dapat dipertanggungjawabkan kebenarannya. Tujuan lainnya adalah untuk mengetahui kemampuan mahasiswa, baik dari segi keterampilan membaca kritis, berpikir logis dari setiap urutan sistematika penulisan, dan mampu untuk melakukan problem solving.

Apabila mahasiswa telah mampu menghasilkan skripsi hingga pada tahap memecahkan permasalahan, hakikatnya skrispi tersebut menunjukkan pada penelitian kuantitatif. Sebagaimana Bahdin dan Ardial, menegaskan bahwa:

Penelitian kuantitatif adalah suatu penelitian yang pada dasarnya menggunakan pendekatan deduktif-induktif. Pendekatan ini berangkat dari suatu kerangka teori, gagasan para ahli, ataupun pemahaman peneliti berdasarkan pengalamannya. Selanjutnya dikembangkan menjadi permasalahan beserta pemecahannya yang diajukan untuk memeroleh pembenaran (verifikasi) dalam bentuk dukungan data empiris di lapangan. ${ }^{3}$

Penelitian kuantitatif inilah yang dominan diminati oleh Mahasiswa PAI di STIT Pemalang. Namun, permasalahan awal yang sering terjadi pada mahasiswa adalah terkait kemampuan membaca. Hal ini sebagaimana Bapak Purnama Razak, M.Ag, mengatakan bahwa "Mahasiswa PAI yang sudah pernah melakukan pengujian skripsi, hampir semua mendapatkan perbaikan (revisi), meskipun pengkategorian perbaikan tersebut ada yang sedikit, sedang dan banyak. Penulisan skripsi yang dipaparkan masih terdapat kekeliruan dalam hal ketersambungan atau kelogisan dalam mengaitkan suatu permasalahan. Ketidakcermatan dalam membaca sebuah literatur inilah sebagai sebab awal kurangnya berpikir logis pada diri mahasiswa.

${ }^{3}$ Bahdin Nur Tanjung dan Ardial, Pedoman Penulisan Karya Ilmiah (Proposal, Skripsi dan Tesis dan Mempersiapkan Diri menjadi Penulis Artikel Ilmiah), (Jakarta: Kencana, 2010), hlm. 2. 
Adapun langkah-langkah yang mahasiswa gunakan dalam membaca buku adalah (1) membaca judul buku, nama pengarang dan tahun penerbitan buku karena dikhawatirkan buku tersebut sudah lama; (2) melihat daftar isi yang sesuai dengan permasalahan yang dicari; (3) setelah ditemukan permasalahan yang dicari, mahasiswa membaca dengan melihat yang sekiranya ada kata atau frase kata yang sesuai dengan permasalahan; (4) mengambil beberapa paragraf yang akan dijadikan rujukan; (5) mengkaitkan paragraf yang satu dan lainnya agar menjadi karya ilmiah."4

Di Universitas atau Perguruan Tinggi, membaca merupakan suatu tuntutan mutlak bagi setiap mahasiswa, karena dapat memperkaya dan memperluas pengetahuannya. Bahkan kecakapan membaca merupakan kegiatan yang utama untuk keberhasilan pendidikan di Perguruan Tinggi, karena sebagai penunjang peningkatan kualitas penulisan skripsi.

Tidak hanya dalam hal membaca, kemampuan memecahkan permasalahan ini pun menjadi salah satu faktor peningkatan kualitas penulisan skripsi. Kemampuan problem solving banyak ditunjang oleh kemampuan menggunakan penalaran atau berpikir logis.

Mahasiswa yang kreatif mutlak didukung oleh sarana berpikir yang lengkap terpadu secara utuh untuk melakukan penelaahan ilmiah secara teratur dan seksama yang akan dituangkan dalam skripsinya. Mempelajari sarana berpikir logis bukanlah sebagai ilmu yang mandiri dan diperoleh dari pengetahuan menurut metode ilmiah yang lazim seperti melalui proses deduktif-induktif. Kesemua sarana berpikir logis tersebut berperan penting dalam fungsinya untuk menyusun argumentasi

${ }^{4}$ Hasil wawancara dengan Bapak Purnama Razak selaku Dosen Pendidikan Agama Islam STIT Pemalang, pada hari Ahad tanggal 7 Mei 2017, pukul 08.00-09.00 WIB. 
dukungan landasan teoritis pengetahuan yang diperoleh dengan metode ilmiah. $^{5}$

Dari permasalahan tersebut, mendorong penulis untuk mengadakan penelitian dengan judul: "Keterampilan Membaca Kritis dan Berpikir Logis dengan Kualitas Penulisan Skripsi Kuantitatif Mahasiswa Pendidikan Agama Islam”.

\section{Keterampilan Membaca Kritis}

Dalam mencari informasi dan memerluas cakrawala pengetahuan, membaca memunyai arti penting. Sebagaimana William dalam mengartikan membaca, "Reading is the ability to draw meaning from the printed page and interpret this information appropriately". ${ }^{6}$ Membaca merupakan keterampilan untuk memeroleh informasi yang mencakup isi dan memahami makna bacaan.

Salah satu jenis membaca adalah membaca secara kritis, yaitu cara membaca dengan melihat motif penulis dan menilainya sehingga pembaca tidak sekadar membaca, tetapi juga berpikir tentang masalah yang dibahas. Hal yang harus diingat dalam membaca kritis adalah bahwa tidak semua yang ditulis itu benar. Oleh sebab itu, pembaca harus mengikuti jalan pikiran penulis dengan cepat, akurat dan kritis. Akurat artinya mampu membedakan hal yang relevan dan tidak relevan. Kritis artinya menerima pemikiran yang ditulis dengan dasar yang baik, logis, benar dan realistis. ${ }^{7}$

${ }^{5}$ Burhanuddin Salam, Cara Belajar Sukses di Perguruan Tinggi, (Jakarta: Rineka Cipta, 2004), hlm. 41.

${ }^{6}$ William Grabe dan Fredricka L. Stoller, Teaching and Researching Reading, (London: Pearson Education, 2002), hlm. 9.

${ }^{7}$ Listiyanto Ahmad, Speed Reading: Teknik dan Metode membaca Cepat, (Yogyakarta: A Plus Book, 2010), hlm. 20. 
Dalam hal ini, pembaca mengolah bahan bacaan secara kritis untuk menemukan keseluruhan makna bahan bacaan, baik makna tersurat maupun tersiratnya, melalui tahap mengenal, memahami, menganalisis, mensintesis dan menilai. Mengolah secara kritis artinya dalam proses membaca seorang pembaca tidak hanya menangkap makna yang tersurat (makna baris-baris bacaan) atau (Reading The Lines), tetapi juga menemukan makna antarbaris (Reading Between The Lines), dan makna di balik baris (Reading Beyond The Lines). ${ }^{8}$

\section{Indikator Keterampilan Membaca Kritis}

Keterampilan membaca kritis ini berkaitan dengan usaha menemukan makna yang tersirat dalam bacaan. Adapun beberapa keterampilan membaca kritis adalah sebagai berikut: (a) keterampilan menemukan informasi faktual, (b) keterampilan menemukan ide pokok yang tersirat, (e) keterampilan menilai kesesuaian antargagasan, (d) keterampilan menilai keruntutan gagasan, dan (e) keterampilan menilai kesesuaian antara judul dan isi bacaan.

\section{Kemampuan Berpikir Logis}

Dalam Kamus Oxford Advanced Learner's Dictionary, istilah thinking, salah satunya diartikan, “ideas or opinies about something". ${ }^{9}$ Pemikiran adalah idea atau opini. Dengan kata lain, orang yang berpikir adalah orang yang memiliki idea atau opini mengenai sesuatu.

Berpikir adalah suatu gejala mental yang bisa menghubungkan hal-hal yang kita ketahui. Ia merupakan proses dialektis. Artinya, selama kita berpikir, dalam pikiran itu terjadi tanya jawab, untuk bisa

\footnotetext{
${ }^{8}$ Nur Hadi, Bagaimana Meningkatkan Kemampuan Membaca: Suatu Teknik Memahami Literatur yang Efisien, (Bandung: Sinar Baru Algensindo, 2004), hlm. 59.

${ }^{9}$ Sudarma Momon, Mengembangkan Keterampilan Berpikir Kreatif, (Jakarta: Rajawali Pers, 2012), hlm. 37..
} 
meletakkan hubungan-hubungan antara pengetahuan kita dengan tepat. Tanya jawab itulah yang memberikan arah kepada pikiran kita. Sedangkan logis artinya yang terbentuk secara prosesual. Misalnya dengan menganalisis, membandingkan, membuat sintesis, dan lainlain. $^{10}$

\section{Indikator Kemampuan Berpikir Logis}

Kemampuan berpikir logis secara implisit dapat dilakukan mulai dari saat pelaku ilmiah melakukan observasi atau pengamatan, merumuskan masalah, menyusun hipotesis, melaksanakan penelitian, mengumpulkan data, mengolah dan menganalisis data sampai menarik kesimpulan.

\section{Kualitas Penulisan Skripsi Kuantitatif}

Skripsi merupakan suatu karya ilmiah seseorang yang lahirdari suatu proses pendidikan. Sebagai salah satu karya ilmiah, maka sudah sewajarnya penulisan skripsi mengikuti suatu persyaratan atau standar ilmiah. Mengenai hal ini Syafri menegaskan bahwa kuallitas "basic" yang seharusnya dimiliki oleh karya ilmiah tidak boleh melanggar nilai-nilai ilmiah yang paling dasar. Skripsi harus tetap sebagai produk ilmiah yang mengikuti persyaratan atau standar ilmiah pula. ${ }^{11}$ Sejalan dengan hal itu, Sekolah Tinggi Ilmu Tarbiyah Pemalang menetapkan suatu pedoman penulisan skripsi bagi mahasiswa. Pedoman penulisan skripsi tersebut dimaksudkan agar penulisan skripsi mengikuti aturan-aturan baku ataustandar ilmiah sehingga mampu melahirkan skripsi yang benar danberkualitas. Kualitas penulisan skripsi dapat menjadi tolok ukur untukmenilai

${ }^{10}$ Mohammad Mustari, Nilai Karakter: Refleksi untuk Pendidikan, (Jakarta: Rajawali Pers, 2014), hlm. 70.

${ }^{11}$ Bahdin Nur Tanjung dan Ardial, Pedoman Penulisan Karya Ilmiah . . . , hlm. 15. 
kredibilitas kesarjanaan. Kredibilitas kesarjanaan antara lain diukur berdasarkan kemampuannya menyusun karya ilmiah dan dengan itu pula ditantang untuk berpikir ilmiah.

Berkaitan dengan kredibilitas kesarjanaan seseorang, skripsi mempunyai peranan dalam kancah akademis di Perguruan Tinggi. Darmono menyebutkan berbagai peran skripsi yaitu; (1) merupakan kegiatan belajar yang mengarahkan mahasiswa untuk mengintegrasikan pengalaman belajarnya dalam menghadapi suatu masalah secara mendalam, (2) merupakan sarana kegiatan belajar mahasiswa untuk meningkatkan kemampuannya dalam mengintegrasikan pengalaman dan keterampilan yang telah diperolehdan (3) memberi peluang kepada mahasiswa untuk melatih diri dalam hal mengemukakan dan menyelesaikan masalah secara mandiri dan ilmiah. ${ }^{12}$

Kemampuan menalar dan mengingat merupakan prasyat berikutnya. Seorang peneliti harus menghubung-hubungkan aneka fenomena baik yang sesuai maupun yang bertentangan. Dia harus mempunyai kemampuan berpikir secara baik secara induktif maupun deduktif, menafsirkan fakta untuk menjadi informasi dan daya penjelas. Kemampuan berpikir orisinil dan objektif harus dimunculkan, karena peneliti harus brilian dan punya keberanian, kreatif dan dapat mengabstraksikan aneka gejala. Kemampuan berpikir orisinil antara lain dibutuhkan pada saat menyusun instrumen, merumuskan asumsi, merumuskan definisi permasalahan dan menarik kesimpulan.

${ }^{12}$ M. Hasan Darmono dan Ani,Menyelesaikan Skripsi Dalam SatuSemester. (Jakarta: Grasindo, 2004), hlm. 30. 


\section{Indikator Kualitas Skrispsi Kuantitatif}

Struktur penulisan skripsi beserta komponen-komponennya biasanya disusun berdasar format yang dianut dan disusun sebagaimana yang disepakati dan ditentukan oleh suatu lembaga. Sistematika penulisan skripsi biasanya terdiri atas tiga bagian, yakni bagian awal, bagian pokok, dan bagian akhir.

\section{B. Metodologi Penelitian}

\section{Variabel penelitian}

Penelitian ini memiliki 2 (dua) variabel bebas dan 1 (satu) variabel terikat. Variabel bebas yang pertama adalah keterampilan membaca kritis $\left(\mathrm{X}_{1}\right)$, berpikir logis $\left(\mathrm{X}_{2}\right)$ dan kualitas skripsi kuantitatif (Y) sebagai variabel terikat.

Konstelasi penelitian dapat digambarkan sebagai berikut:

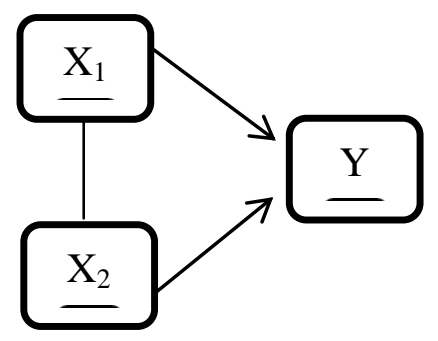

\section{Pengajuan hipotesis penelitian}

a. Terdapat hubungan positif antara keterampilan membaca kritis dengan kualitas penulisan skripsi kuantitatif

b. Terdapat hubungan positif antara berpikir logis dengan kualitas skripsi kuantitatif

c. Terdapat hubungan positif antara keterampilan membaca kritis dan berpikir logis dengan kualitas skripsi kuantitatif

\section{Populasi dan sampling}

Populasi adalah wilayah generalisasi yang terdiri atas obyek atau subyek yang mempunyai kuantitas dan karakteristik tertentu 
yang ditetapkan oleh peneliti untuk dipelajari dan kemudian ditarik kesimpulannya. ${ }^{13}$ Adapun jenis populasi yang digunakan dalam penelitian ini adalah populasi terbatas, mempunyai sumber data yang jelas batasnya secara kuantitatif sehingga dapat dihitung jumlahnya. ${ }^{14}$ Sehingga dalam penelitian ini populasi yang digunakan adalah keseluruhan Mahasiswa PAI Tahun Pelajaran 2013-2014 yang berjumlah 100 mahasiswa.

Sampel yang digunakan menggunakan sampel Proportionate Stratified Random Sampling. Sampel Proportionate Stratified Random Sampling merupakan teknik yang digunakan bila populasi mempunyai anggota/unsur yang tidak homogen dan berstrata secara proporsional. ${ }^{15}$ Sehingga untuk menentukan jumlah sampel, penulis gunakan Proportionate Stratified Random Sampling hasil yang diperoleh dari 100 Mahasiswa yaitu 65 Mahasiswa sebagai responden.

\section{Metode penelitian}

Metode penelitian yang digunakan oleh peneliti dengan metode penelitian kuantitatif, yaitu penelitian yang banyak dituntut dengan angka mulai dari pengumpulan data, penafsiran terhadap data tersebut, serta penampilan dari hasilnya. ${ }^{16}$ Sedangkan analisis data dalam penelitian ini dengan menggunakan analisis korelasi product moment dan regresi linear ganda.

\footnotetext{
${ }^{13}$ Sugiyono, Metode Penelitian Pendidikan, hlm. 117.

${ }^{14}$ Riduwan, Dasar-dasar Statistika, (Bandung: Alfabeta, 2008), hlm. 8.

${ }^{15}$ Sugiyono, Metode Penelitian Pendidikan, hlm. 201.

${ }^{16}$ Sugiyono, Metode Penelitian Pendidikan: Pendekatan Kuantitatif, Kualitatif, dan
} $R \&$ D (Bandung: Alfabeta, 2007) hlm. 12 


\section{Teknik pengumpulan data}

Pengumpulan data dalam penelitian ini menggunakan kuesioner/angket, wawancara dan dokumentasi. Adapun pengembangan instrumen ditempuh melalui beberapa langkah, diantaranya: (1) menyusun indikator setiap variabel berdasarkan teori pada setiap variabel; (2) menyusun kisi-kisi instrumen masingmasing variabel; (3) menyusunbutir-butir soal dan penetapan skala pengukurannya; (4) melakukan uji coba instrumen, dan (5) melakukan uji coba validasi dan reabilitas instumen penelitian.

\section{Hasil Penelitian}

\section{Analisis Deskriptif}

Dalam analisis ini akan dideskripsikan tentang keterampilan membaca kritis dan berpikir logis dengan kualitas penulisan skripsi kuantitatif Mahasiswa PAI STIT Pemalang Tahun Ajaran 20132014. Adapun analisis deskriptifnya sebagai berikut:

\section{a. Keterampilan Membaca Kritis}

Setelah melakukan penelitian, data keterampilan membaca kritisdiperoleh hasiluji coba instrumen dari 25 item soal menghasilkan 20 item soal yang dinyatakan valid dan reliabel. Soal yang berjumlah 20 item tersebut, kemudian disebarkan kepada 65 Mahasiswa PAI STIT Pemalang sebagai responden penelitian.

Untuk mengetahui keterampilan membaca kritis Mahasiswa, maka peneliti menyajikan data yang diperoleh dengan menjumlahkan skor jawaban angket dari responden. Kemudian dapat menentukan tabel distribusi frekuensi menggunakan program SPSS 16. 
Tabel Descriptive Statistics

\begin{tabular}{|l|r|r|r|r|r|}
\hline & $\mathrm{N}$ & Minimum & Maximum & Mean & Std. Deviation \\
\hline Keterampilan membaca kritis & 65 & 28.00 & 62.00 & 45.3692 & 9.77812 \\
Valid N (listwise) & 65 & & & & \\
\hline
\end{tabular}

Dari tabel diketahui nilai rata-rata (mean) variabel keterampilan membaca kritis sebesar 45,37 dan nilai standar deviasi sebesar 9,78. Dengan demikian dapat diketahui distribusi frekuensi sebagai berikut.

Tabel 1. Distribusi Frekuensi Data Variabel Keterampilan Membaca Kritis

\begin{tabular}{|c|l|c|c|c|}
\hline No & \multicolumn{1}{|c|}{ Kriteria } & Skor & F & Prosentase \\
\hline 1 & Sangat baik & $>60$ & 4 & 6,2 \\
2 & Baik & $51-60$ & 18 & 27,7 \\
3 & Cukup & $41-50$ & 22 & 33,8 \\
4 & Kurang & $31-40$ & 13 & 20 \\
5 & Sangat kurang & $<30$ & 8 & 12,3 \\
\hline \multicolumn{2}{|r|}{ Total } & 65 & 100 \\
\hline
\end{tabular}

Dari tabel di atas dapat diketahui bahwa keterampilan membaca kritis Mahasiswa PAI STIT Pemalang Tahun Ajaran 2013-2014 dalam kategori "cukup" yaitu pada interval 41-50 dengan nilai rata-rata 45,37 .

\section{b. Kemampuan Berpikir Logis}

Setelah melakukan penelitian, data kemampuan berpikir logisdiperoleh hasiluji coba instrumen dari30 item soal menghasilkan 22 item soalyang dinyatakan valid dan reliabel. Soal yang berjumlah 22 item tersebut, kemudian disebarkan kepada 65 Mahasiswa PAI STIT Pemalangsebagai responden penelitian. 
Untuk mengetahui kemampuan berpikir logis Mahasiswa, maka peneliti menyajikan data yang diperoleh dengan menjumlahkan skor jawaban angket dari responden. Kemudian dapat menentukan tabel distribusi frekuensi menggunakan program SPSS 16.

Tabel Descriptive Statistics

\begin{tabular}{|l|r|r|r|r|r|}
\hline & $\mathrm{N}$ & Minimum & Maximum & Mean & \multicolumn{1}{c|}{ Std. Deviation } \\
\hline Berpikir Logis & 65 & 33.00 & 67.00 & 47.4000 & 9.15287 \\
Valid N (listwise) & 65 & & & & \\
\hline
\end{tabular}

Dari tabel diketahui nilai rata-rata (mean) variabel berpikir logis sebesar 47,40 dan nilai standar deviasi sebesar 9,15. Dengan demikian dapat diketahui distribusi frekuensi sebagai berikut.

Tabel 2. Distribusi Frekuensi Data Variabel Kemampuan Berpikir Logis

\begin{tabular}{|c|l|c|c|c|}
\hline No & \multicolumn{1}{|c|}{ Kriteria } & Skor & F & Prosentase \\
\hline 1 & Sangat baik & $>61$ & 3 & 4,6 \\
2 & Baik & $53-61$ & 20 & 30,8 \\
3 & Cukup & $44-52$ & 24 & 36,9 \\
4 & Kurang & $35-43$ & 13 & 20 \\
5 & Sangat kurang & $<35$ & 5 & 7,7 \\
\hline \multicolumn{2}{|c|}{ Total } & 65 & 100 \\
\hline
\end{tabular}

Dari tabel dapat diketahui bahwa berpikir logis pada Mahasiswa PAI STIT Pemalang Tahun Ajaran 2016/2017 dalam kategori "cukup" yaitu pada interval 44-52 dengan nilai rata-rata 47,40

\section{c. Kualitas Penulisan Skripsi Kuantitatif Mahasiswa PAI}

Setelah melakukan penelitian, data kualitas penulisan skripsi kuantitatif Mahasiswa diperoleh hasil uji coba instrumen dari 25 item soal menghasilkan 19 item soal yang dinyatakan 
valid dan reliabel. Soal yang berjumlah 19 item tersebut, kemudian disebarkan kepada 65 Mahasiswa PAI STIT Pemalang sebagai responden penelitian.

Untuk mengetahui kualitas penulisan skripsi kuantitatif Mahasiswa, maka peneliti menyajikan data yang diperoleh dengan menjumlahkan skor jawaban angket dari responden. Kemudian dapat menentukan tabel distribusi frekuensi menggunakan program SPSS 16.

Tabel Descriptive Statistics

\begin{tabular}{|l|r|r|r|r|l|}
\hline & $\mathrm{N}$ & Minimum & Maximum & Mean & \multicolumn{1}{|l|}{ Std. Deviation } \\
\hline $\begin{array}{l}\text { kualitas skripsi } \\
\text { kuantitatif }\end{array}$ & 65 & 45 & 75 & 63.68 & \\
Valid N (listwise) & 65 & & & & \\
\hline
\end{tabular}

Dari tabel diketahui nilai rata-rata (mean) variabel kualitas skripsi kuantitatif sebesar 63,68 dan nilai standar deviasi sebesar 8,55. Dengan demikian dapat diketahui distribusi frekuensi sebagai berikut.

Tabel 3. Distribusi Frekuensi Data Variabel Kualitas Penulisan Skripsi Kuantitatif

\begin{tabular}{|c|l|c|c|c|}
\hline No & \multicolumn{1}{|c|}{ Kriteria } & Skor & F & Prosentase \\
\hline 1 & Sangat baik & $>72$ & 2 & 3,1 \\
2 & Baik & $65-71$ & 10 & 15,4 \\
3 & Cukup & $58-64$ & 27 & 41,5 \\
4 & Kurang & $50-57$ & 20 & 30,8 \\
5 & Sangat kurang & $<49$ & 6 & 9,2 \\
\hline \multicolumn{2}{|c|}{ Total } & 65 & 100 \\
\hline
\end{tabular}

Dari tabel dapat diketahui bahwa berpikir logis pada Mahasiswa PAI STIT Pemalang Tahun Ajaran 2016/2017 dalam kategori "cukup" yaitu pada interval 44-52 dengan nilai rata-rata 63,68 . 


\section{d. Analisis Uji Persyaratan}

Adapun tujuan dari penggunaan uji normalitas adalah untuk mengetahui apakah data berasal dari populasi berdistribusi normal atau tidak. Data yang digunakan dalam uji normalitas ini adalah data keterampilan membaca kritis $\left(\mathrm{X}_{1}\right)$, kemampuan berpikir logis $\left(\mathrm{X}_{2}\right)$ dan kualitas penulisan skripsi kuantitatif (Y). Untuk teknik pengujian normalitas peneliti menggunakan teknik KolmogorovSmirnov $Z$ yang dihitung dengan bantuan SPSS tipe 16 .

Berdasarkan skor data penelitian di atas, dapat dilakukan perhitungan uji normalitas melalui software SPSS tipe 16 dan menghasilkan output sebagai berikut:

Tabel 4. Hasil uji Kolmogorov-Smirnov

\begin{tabular}{|l|c|c|l|}
\hline \multicolumn{1}{|c|}{ Variabel } & KS-Z & $\mathrm{P}$ & Keterangan \\
\hline Keterampilan membaca kritis $\left(\mathrm{X}_{1}\right)$ & 0,797 & 0,549 & Normal \\
Kemampuan berpikir logis $\left(\mathrm{X}_{2}\right)$ & 1,047 & 0,223 & Normal \\
Kualitas penulisan skripsi kuantitatif $(\mathrm{Y})$ & 1,001 & 0,258 & Normal \\
\hline
\end{tabular}

Berdasarkan perhitungan uji normalitas dengan Kolmogorov Smirnov $Z$ pada ketiga variabel yaitu keterampilan membaca kritis $\left(\mathrm{X}_{1}\right)$, kemampuan berpikir logis $\left(\mathrm{X}_{2}\right)$ dan kualitas penulisan skripsi kuantitatif (Y) diperoleh hasil perhitungan uji normalitas dengan nilai KSZ dan Asymp.Sig. lebih besar dari 0,05 maka dapat disimpulkan data berdistribusi normal.

Pedoman yang digunakan untuk menguji linearitas garis regresi dilakukan dengan jalan menguji signifikansi nilai $\mathrm{F}$ pada baris deviation from linearity. Adapun hasil uji linearitas disajikan pada Tabel. 5 
Tabel. 5 Hasil Uji Linearitas

\begin{tabular}{|l|c|c|l|}
\hline \multicolumn{1}{|c|}{ Variabel } & $\mathrm{F}$ & $\mathrm{P}$ & Keterangan \\
\hline Keterampilan membaca kritis $\left(\mathrm{X}_{1}\right)$ & 1,261 & 0,121 & Linear \\
Kemampuan berpikir logis $\left(\mathrm{X}_{2}\right)$ & 1,110 & 0,293 & Linear \\
\hline
\end{tabular}

Nilai p antara keterampilan membaca kritis $\left(\mathrm{X}_{1}\right)$ dan kualitas skripsi kuantitatif (Y) sebesar 0,121 atau lebih besar dari 0,05 maka hubungan antara kedua variabel tersebut linear. Nilai $\mathrm{p}$ antara kemampuan berpikir logis $\left(\mathrm{X}_{2}\right)$ dan kualitas skripsi kuantitatif $(\mathrm{Y})$ sebesar 0,293 atau lebih besar dari 0,05 maka hubungan antara kedua variabel tersebut linear.

Uji multikolinearitas untuk mengetahui adanya hubungan antara beberapa atau semua variabel yang menjelaskan dalam model regresi. Jika dalam model terdapat multikolinearitas maka model tersebut memiliki kesalahan standar yang besar sehingga koefisien tidak dapat ditaksir dengan ketetapan yang tinggi. Salah satu cara mendeteksi ada tidaknya multikolinearitas adalah dengan melihat nilai VIF. Hasil uji multikolinearitas disajikan pada tabel 6.

Tabel. 6 Hasil Uji Multikolinearitas

\begin{tabular}{|l|c|}
\hline \multicolumn{1}{|c|}{ Variabel } & VIF \\
\hline Keterampilan membaca kritis $\left(\mathrm{X}_{1}\right)$ & 1,059 \\
Kemampuan berpikir logis $\left(\mathrm{X}_{2}\right)$ & 1,059 \\
\hline
\end{tabular}

Berdasarkan hasil perhitungan di atas nilai VIF pada variabel keterampilan membaca kritis sebesar 1,059 atau lebih kecil dari 10 maka tidak ada gejala multikolinearitas. Nilai VIF pada variabel kemampuan berpikir logis sebesar 1,059 atau lebih kecil dari 10 maka tidak ada gejala multikolinearitas. Nilai toleransi yang 
mendekati angka 1 juga menunjukkan tidak adanya multikolinearitas.

\section{e. Analisis Uji Hipotesis}

Pengujian hipotesis dilaksanakan untuk membuktikan apakah hipotesis yang diajukan yang sifatnya sementara benar-benar terbukti atau tidak. Persyaratan uji normalitas, linearitas dan multikolinearitas sudah terpenuhi dan untuk mengetahui hubungan antara variabel bebas dengan variabel terikat maka dilakukan uji hipotesis. Penelitian ini menggunakan teknik analisis korelasi product moment dan regresi ganda denagn dua prediktor untuk mengetahui hubungan variabel bebas yaitu keterampilan membaca kritis $\left(\mathrm{X}_{1}\right)$ dan kemampuan berpikir logis $\left(\mathrm{X}_{2}\right)$ secara bersama-sama dengan variabel terikat kualitas skripsi (Y).

Hasil pengujian korelasi product moment disajikan pada tabel 7 .

Tabel. 7 Hasil Pengujian Korelasi Product Moment

\begin{tabular}{|ll|c|c|c|}
\hline & & $\begin{array}{c}\text { Keterampilan } \\
\text { membaca kritis }\end{array}$ & $\begin{array}{c}\text { Kemampuan } \\
\text { berpikir logis }\end{array}$ & $\begin{array}{c}\text { Kualitas skripsi } \\
\text { kuantitatif }\end{array}$ \\
\hline Keterampilan & $\mathrm{r}$ & 1 & & 0,480 \\
membaca kritis & $\mathrm{p}$ & & 1 & 0,000 \\
Kemampuan & $\mathrm{r}$ & & & 0,453 \\
berpikir logis & $\mathrm{p}$ & & 0,453 & 0,000 \\
Kualitas skripsi & $\mathrm{r}$ & 0,480 & 0,000 & 1 \\
kuantitatif & $\mathrm{p}$ & 0,000 & & \\
\hline
\end{tabular}

Hasil pengujian regresi ganda dengan dua prediktor disajikan pada tabel 8 .

Tabel 8. Hasil Pengujian Regresi Ganda dengan Dua Prediktor

\begin{tabular}{|c|c|c|c|c|c|}
\hline Model & Kof. Reg. & SE & B & $\mathrm{t}$ & $\mathrm{P}$ \\
\hline Konstan & 17,414 & 3,599 & & 4,838 & 0,000 \\
\hline $\begin{array}{l}\text { Keterampilan membaca } \\
\text { kritis }\end{array}$ & 0,420 & 0,050 & 0,396 & 8,416 & 0,000 \\
\hline $\begin{array}{l}\text { Kemampuan berpikir } \\
\text { logis }\end{array}$ & 0,405 & 0,053 & 0,360 & 7,650 & 0,000 \\
\hline
\end{tabular}




\begin{tabular}{|l|l|l|l|l|l|}
\hline $\mathrm{R}=0,594$ & & & & & \\
$\mathrm{R}^{2}=0,353$ & & & & & \\
$\mathrm{~F}=84,547$ & & & & & 0,000 \\
\hline
\end{tabular}

\section{Pengujian Hipotesis Pertama}

Hipotesis alternatif pertama $\left(\mathrm{H}_{\mathrm{a} 1}\right)$ dalam penelitian ini berbunyi "Ada hubungan yang positif dan signifikan keterampilan membaca kritis dengan kualitas penulisan skripsi kuantitatif Mahasiswa PAI". Pada pengujian secara statistik hipotesis alternatif dirubah menjadi hipotesis statistik atau hipotesis nihil $\left(\mathrm{H}_{01}\right)$ dan berbunyi "Tidak ada hubungan yang positif dan signifikan keterampilan membaca kritis dengan kualitas penulisan skripsi kuantitatif Mahasiswa PAI”.

Berdasarkan hasil pengujian korelasi product moment keterampilan membaca kritis dengan kualitas penulisan skripsi kuantitatif didapatkan nilai r-hitung sebesar 0,480 dengan $\mathrm{p}$ sebesar 0,000. Berdasarkan nilai $\mathrm{p}<0,05$, maka $\mathrm{H}_{0}$ ditolak sehingga disimpulkan ada hubungan yang positif antara keterampilan membaca kritis dengan kemampuan berpikir logis. Semakin baik keterampilan membaca kritis semakin baik pula kualitas penulisan skripsi kuantitatif.

\section{Pengujian Hipotesis Kedua}

Hipotesis alternatif kedua $\left(\mathrm{H}_{\mathrm{a} 2}\right)$ dalam penelitian ini berbunyi "Ada hubungan yang positif dan signifikan kemampuan berpikir logis dengan kualitas penulisan skripsi kuantitatif Mahasiswa PAI". Pada pengujian secara statistik hipotesis alternatif dirubah menjadi hipotesis statistik atau hipotesis nihil $\left(\mathrm{H}_{02}\right)$ dan berbunyi "Tidak ada hubungan yang 
positif dan signifikan kemampuan berpikir logis dengan kualitas penulisan skripsi kuantitatif Mahasiswa PAI".

Berdasarkan hasil pengujian korelasi product moment kemampuan berpikir logis dengan kualitas penulisan skripsi kuantitatif nilai r-hitung sebesar 0,453 dengan p sebesar 0,000. Berdasarkan nilai $\mathrm{p}<0,05$ maka $\mathrm{H}_{0}$ di tolak sehingga disimpulkan ada hubungan yang positif antara kemampuan berpikir logis dengan kualitas penulisan skripsi kuantitatuf. Semakin baik kemampuan berpikir logis maka semakin baik pula kualitas penulisan skripsi kuantitatif.

\section{Pengujian Hipotesis Ketiga}

Hipotesis alternatif ketiga $\left(\mathrm{H}_{\mathrm{a} 3}\right)$ dalam penelitian ini berbunyi "Ada hubungan yang positif dan signifikan keterampilan membaca kritis dan kemampuan berpikir logis dengan kualitas penulisan skripsi kuantitatif Mahasiswa PAI". Pada pengujian secara statistik hipotesis alternatif dirubah menjadi hipotesis statistik atau hipotesis nihil $\left(\mathrm{H}_{03}\right)$ dan berbunyi "Tidak ada hubungan yang positif dan signifikan keterampilan membaca kritis dan kemampuan berpikir logis dengan kualitas penulisan skripsi kuantitatif Mahasiswa PAI".

Berdasarkan hasil pengujian korelasi product moment keterampilan membaca kritis dengan kualitas penulisan skripsi kuantitatif didapatkan nilai F-hitung sebesar 84,547 dengan $\mathrm{p}$ sebesar 0,000. Berdasarkan nilai $\mathrm{p}<0,05$, maka $\mathrm{H}_{0}$ ditolak sehingga disimpulkan ada hubungan yang positif antara keterampilan membaca kritis dan kemampuan berpikir logis dengan kemampuan berpikir logis. Semakin baik keterampilan 
membaca kritis dan kemampuan berpikir logis maka semakin baik pula kualitas penulisan skripsi kuantitatif.

\section{Pembahasan}

\section{Keterampilan Membaca Kritis Dengan Kualitas Skripsi Kuantitatif}

Hasil penelitian didapatkan hubungan yang positif antara keterampilan membaca kritis dengan kemampuan berpikir logis. Semakin baik keterampilan membaca kritis semakin baik pula kualitas penulisan skripsi kuantitatif.

Dengan membaca, mahasiswa akan sering menemukan sejumlah informasiyang membuatnya lebih tahu. Dari hasil membaca, siswa juga terlatih untukmenghubungkan beragam konsep sehingga menjadi rangkaian konsep yangmempunyai arti bagi dirinya, yang pada akhirnya menambah kekayaan informasiyang sudah dimilikinya. Penambahan informasi ini banyak dilakukan denganmembaca berbagai media yang sesuai dengan kebutuhannya. Darititik ini, kemudian timbul minat baca seorang mahasiswa agar memperoleh informasiuntuk kepentingan kehidupannya.

\section{Kemampuan Berpikir Logis Dengan Kualitas Skripsi Kuantitatif}

Hasil penelitian didapatkan hubungan yang positif antara kemampuan berpikir logis dengan kualitas penulisan skripsi kuantitatuf. Semakin baik kemampuan berpikir logis maka semakin baik pula kualitas penulisan skripsi kuantitatif.

Kerangka berpikir dapat berupa kerangka teori dan dapat pula berbentuk kerangka penalaran logis. Kerangka teori itu merupakan uraian ringkas tentang teori yang digunakan dan cara menggunakan teori itu dalam menjawab pertanyaan penelitian. Kerangka penalaran logis merupakan urutan berpikir logis, sebagai suatu ciri cara berpikir 
ilmiah yang akan digunakan, dan cara menggunakan logika tersebut dalam memecahkan masalah. Kerangka berpikir itu bersifat operasional yang diturunkan dari satu atau beberapa teori atau dari pernyataan-pernyataan yang logis. Ia berhubungan dengan masalah penelitian dan menjadi pedoman dalam perumusan hipotesis yang akan diajukan.

Berpikir secara logis adalah suatu proses berpikir dengan menggunakan logika, rasional dan masuk akal. Secara etymologis logika berasal dari kata logos yang mempunyai dua arti 1) pemikiran 2) kata-kata. Jadi logika adalah ilmu yang mengkaji pemikiran. Karena pemikiran selalu diekspresikan dalam kata-kata, maka logika juga berkaitan dengan "kata sebagai ekspresi dari pemikiran". Dengan berpikir logis, kita akan mampu membedakan dan mengkritisi kejadian-kejadian yang terjadi pada kita saat ini apakah kejadian-kejadian itu masuk akal dan sesuai dengan ilmu pengetahuan atau tidak. Tidak hanya itu, seorang peserta didik juga harus mampu berpikir kritis sehingga ia mampu mengolah fenomenafenomena yang diterima oleh sistem indera hingga dapat memunculkan berbagai pertanyaan yang berkaitan dan menggelitik untuk dicari jawabannya. ${ }^{17}$

Contoh realnya ketika seorang mahasiswa atau peneliti melakukan metode ilmiah, maka pelaku ilmiah ini harus melakukan kegiatan ilmiah ini dengan berpikir secara logis, mulai dari saat pelaku ilmiah melakukan observasi/pengamatan, merumuskan masalah, menyusun hipotesis, melaksanakan penelitian, mengumpulkan data, mengolah dan menganalisis data, hingga

${ }^{17}$ Surya Hendra, Cara Belajar Orang Genius, (Jakarta: Elex Media Komputindo, 2013), hlm. 3. 
menarik kesimpulan. Seluruh proses kerja ilmiah tersebut harus dikerjakan berdasarkan prinsip yang logis, rasional, dan masuk akal agar dapat dipertanggungjawabkan.

Cara berpikir logis yang biasa dikembangkan, dapat dibagi menjadi dua, yaitu berpikir secara deduktif dan berpikir secara induktif. Logika deduktif adalah penarikan kesimpulan yang diambil dari proposisi umum ke proposisi khusus. Sederhananya kata umumkhusus. Adapun logika induktif kebalikan dari logika deduktif. Jenis logika ini harus mengikuti penalaran yang berdasarkan pengalaman atau kenyataan. Artinya, jika tidak ada bukti maka kesimpulannya belum tentu benar atau pasti. Dengan demikian, dia tidak akan mempercayai suatu kesimpulan yang tidak berdasarkan pengalaman atau kenyataan lewat tangkapan panca indranya.

\section{E. Simpulan dan Saran}

\section{Simpulan}

Secara rinci kesimpulan dari hasil penelitian dapat diuraikan sebagai berikut:

1. Ada hubungan yang positif antara keterampilan membaca kritis dengan kemampuan berpikir logis. Semakin baik keterampilan membaca kritis semakin baik pula kualitas penulisan skripsi kuantitatif.

2. Ada hubungan yang positif antara kemampuan berpikir logis dengan kualitas penulisan skripsi kuantitatuf. Semakin baik kemampuan berpikir logis maka semakin baik pula kualitas penulisan skripsi kuantitatif.

3. Ada hubungan yang positif antara keterampilan membaca kritis dan kemampuan berpikir logis dengan kemampuan berpikir logis. Semakin baik keterampilan membaca kritis dan kemampuan 
berpikir logis maka semakin baik pula kualitas penulisan skripsi kuantitatif.

\section{Saran}

Berdasarkan hasil penelitian dan kesimpulan yang telah dipaparkan di atas, maka dapat diajukan beberapa saran sebagai berikut:

1. Mahasiswa diharapkan menelaah buku secara mendalam sehingga benar-benar memahami dan menguasai isinya.

2. Mahasiswa mampu untuk terbiasa menangani atau memecahkan masalah, dimana kemampuan problem solving itu banyak ditunjang oleh kemampuan menggunakan penalaran.

3. Mahasiswa diharapkan agar memerhatikan kembali penulisan skripsi sesuai bahan bacaan yang dipahami dan kelogisan dalam penulisannya. 


\section{DAFTAR PUSTAKA}

Achmad Slamet berjudul "Faktor-Faktor yang Berpengaruh terhadap Kualitas Penulisan Skripsi Mahasiswa", jurnal.

Ahmad, Listiyanto. 2010. Speed Reading: Teknik dan Metode membaca Cepat. Yogyakarta: A Plus Book.

Dalman. 2015. Menulis Karya Ilmiah. Jakarta: Rajawali Pers.

Darmono, M. Hasan dan Ani, 2004. Menyelesaikan Skripsi Dalam Satu Semester. Jakarta: Grasindo.

Grabe, William dan Fredricka L. Stoller. 2002. Teaching and Researching Reading, London: Pearson Education.

Hadi, Nur. 2004. Bagaimana Meningkatkan Kemampuan Membaca: Suatu Teknik Memahami Literatur yang Efisien, Bandung: Sinar Baru Algensindo.

Hendra, Surya. 2013. Cara Belajar Orang Genius, Jakarta: Elex Media Komputindo.

Momon, Sudarma. 2012. Mengembangkan Keterampilan Berpikir Kreatif, Jakarta: Rajawali Pers..

Mustari, Mohammad. 2014. Nilai Karakter: Refleksi untuk Pendidikan, Jakarta: Rajawali Pers.

Riduwan. 2008. Dasar-dasar Statistika. Bandung: Alfabeta.

Salam, Burhanuddin. 2004. Cara Belajar Sukses di Perguruan Tinggi, Jakarta: Rineka Cipta

Sugiyono. 2007. Metode Penelitian Pendidikan: Pendekatan Kuantitatif, Kualitatif, dan R\& D. Bandung: Alfabeta.

Tanjung, Bahdin Nur dan Ardial. 2010. Pedoman Penulisan Karya Ilmiah (Proposal, Skripsi dan Tesis dan Mempersiapkan Diri menjadi Penulis Artikel Ilmiah). Jakarta: Kencana.

Tati Sri Uswati berjudul "Penggunaan Bahasa Ilmiah pada Penulisan Skripsi: Problematika dan Alternatif Solusinya”, jurnal. 